\title{
Kroppenstedtia eburnea gen. nov., sp. nov., a thermoactinomycete isolated by environmental screening, and emended description of the family Thermoactinomycetaceae Matsuo et al. 2006 emend. Yassin et al. 2009
}

Correspondence Hans-Peter Klenk hpk@dsmz.de

\author{
Mathias von Jan, ${ }^{1}$ Nicole Riegger, ${ }^{2}$ Gabriele Pötter, ${ }^{1}$ Peter Schumann, ${ }^{1}$ \\ Susanne Verbarg, ${ }^{1}$ Cathrin Spröer, ${ }^{1}$ Manfred Rohde, ${ }^{3}$ Bettina Lauer, ${ }^{2}$ \\ David P. Labeda ${ }^{4}$ and Hans-Peter Klenk ${ }^{1}$ \\ 1DSMZ - German Collection of Microorganisms and Cell Cultures, 38124 Braunschweig, Germany \\ ${ }^{2}$ Microbiology, Vetter Pharma-Fertigung GmbH \& Co. KG, 88212 Ravensburg, Germany \\ ${ }^{3} \mathrm{HZI}$ - Helmholtz Centre for Infection Research, 38124 Braunschweig, Germany \\ ${ }^{4}$ National Center for Agricultural Utilization Research, USDA-ARS, Peoria, IL 61604, USA
}

\begin{abstract}
A Gram-positive, spore-forming, aerobic, filamentous bacterium, strain JFMB-ATE ${ }^{\top}$, was isolated in 2008 during environmental screening of a plastic surface in grade $C$ in a contract manufacturing organization in southern Germany. The isolate grew at temperatures of $25-50{ }^{\circ} \mathrm{C}$ and at $\mathrm{pH}$ 5.0-8.5, forming ivory-coloured colonies with sparse white aerial mycelia.

Chemotaxonomic and molecular characteristics of the isolate matched those described for members of the family Thermoactinomycetaceae, except that the cell-wall peptidoglycan contained LL-diaminopimelic acid, while all previously described members of this family display this diagnostic diamino acid in meso-conformation. The DNA G+C content of the novel strain was $54.6 \mathrm{~mol} \%$, the main polar lipids were diphosphatidylglycerol, phosphatidylethanolamine and phosphatidylglycerol, and the major menaquinone was MK-7. The major fatty acids had saturated $\mathrm{C}_{14}-\mathrm{C}_{16}$ branched chains. No diagnostic sugars were detected. Based on the chemotaxonomic results and $16 \mathrm{~S}$ rRNA gene sequence analysis, the isolate is proposed to represent a novel genus and species, Kroppenstedtia eburnea gen. nov. sp. nov. The type strain is JFMB-ATE ${ }^{\top}$ (=DSM $45196^{\top}=$ NRRL B $-24804^{\top}=$ CCUG $59226^{\top}$ ).
\end{abstract}

Based on morphological characteristics, the filamentous, Gram-positive species of the genus Thermoactinomyces were initially considered to belong to the order Actinomycetales, before they were placed within the distinct family Bacillaceae, primarily due to phylogenetic studies of the 16S rRNA gene (Stackebrandt \& Woese, 1981), but in agreement with phenotypic features such as DNA G+C content and endospore formation (Cross et al. 1968). Later, the members of the genus Thermoactinomyces were divided into the genera Thermoactinomyces, Laceyella, Thermoflavimicrobium and Seinonella (Yoon et al. 2005), corresponding to distinct phylogenetic groups with respective phenotypic characters, such as unique profiles of menaquinone and cellular fatty acid compositions. The

Abbreviation: DAP, diaminopimelic acid.

The GenBank/EMBL/DDBJ accession number for the $16 \mathrm{~S}$ rRNA gene sequence of strain JFMB-ATE $^{\top}$ is FN665656. genus Planifilum (Hatayama et al. 2005) joined this group, which was subsequently reunited by the introduction of the family Thermoactinomycetaceae (within the order Bacillales), together with the genus Mechercharimyces (Matsuo et al. 2006). More recently, the genera Shimazuella (Park et al. 2007) and Desmospora (Yassin et al. 2009) were included in the family Thermoactinomycetaceae. Most species of this family are thermophilic, as indicated by the family name [Gr. adj. thermos hot; Gr. n. aktis -inos ray, beam; Gr. masc. n. mukês a mushroom, anything shaped like a mushroom; N.L. masc. n. Thermoactinomycetes heat (loving) ray fungus], although several of the member genera, such as Seinonella, Mechercharimyces and Shimazuella, are mesophilic. Strains of the family Thermoactinomycetaceae have been isolated from different sources such as mouldy hay, cereal grains, soil, mushroom compost, river water, marine sediments, dairy products, humidifiers of air-conditioning systems, sputa from a patient with suspected pulmonary tuberculosis and other clinical and environmental sources. 
Strain JFMB-ATE ${ }^{\mathrm{T}}$ was isolated during environmental screening of a plastic surface in grade $\mathrm{C}$ in a contract manufacturing organization in southern Germany, using TSA (tryptic soy agar; tryptic soy from Becton Dickinson) medium at a temperature between 30 and $35{ }^{\circ} \mathrm{C}$. The organism was cultivated on Brain Heart Infusion agar (BHI; Becton Dickinson), initially at $28{ }^{\circ} \mathrm{C}$ and subsequently at $40{ }^{\circ} \mathrm{C}$. For the determination of morphological characteristics according to Shirling \& Gottlieb (1966), strain JFMB-ATE ${ }^{\mathrm{T}}$ was cultivated on the four suggested media (yeast extract-malt extract agar, oatmeal agar, inorganic salts-starch agar and glycerol-asparagine agar), together with cultivation on media from DSMZ (List of growth media; http://www.dsmz.de/microorganisms/media list.php): GPHF medium (DSMZ-medium 553), trypticase soy broth agar (535) and GYM Streptomyces medium (65). Electron micrographs were taken with a scanning electron microscope (DSM 982 Gemini; Zeiss) and light microscopic images were made with $\times 400$ magnification and phasecontrast illumination using a Zeiss Axio Scope A1. In both cases, mycelia of strain JFMB-ATE ${ }^{\mathrm{T}}$, which were grown for 3 days in liquid $\mathrm{BHI}$ medium at $45^{\circ} \mathrm{C}$, were examined. Growth rates were determined at temperatures from 25 to $60{ }^{\circ} \mathrm{C}$ and at $\mathrm{pH}$ 5.0, 5.5, 6.0, 6.5, 7.0, 7.5, 8.0 and 8.5. Production of endospores was tested by exposure of the cells to $98{ }^{\circ} \mathrm{C}$ for distinct intervals ( $10 \mathrm{~min}, 30 \mathrm{~min}, 1 \mathrm{~h}, 2 \mathrm{~h}, 4 \mathrm{~h}$ ) followed by transfer to agar plates at $45{ }^{\circ} \mathrm{C}$ and evaluation for viable cells after a period of 2 days. The production of melanoid pigments was investigated by cultivation of strain $\mathrm{JFMB}^{-\mathrm{ATE}^{\mathrm{T}} \text { on }}$ tyrosine agar (DSMZ medium 5011; L-tyrosine from Merck) and peptone-iron agar (DSMZ medium 5010; peptone from Merck). Degradation of specific substrates was examined using agar plates with various basal media. Casein degradation was tested on plates containing milk powder $(5 \%, w / v), \mathrm{NaCl}$ $(0.5 \%)$ and agarose $(1.0 \%)$; positive results are indicated by clear zones around the colonies. Gelatin degradation was examined on plates containing nutrient broth $(0.8 \%)$, gelatin $(0.4 \%)$ and agarose $(1.5 \%)$. After growth, plates were covered with $0.5 \mathrm{M} \mathrm{H}_{2} \mathrm{SO}_{4}$, saturated with $\mathrm{Na}_{2} \mathrm{SO}_{4}$ solution at $55{ }^{\circ} \mathrm{C}$; positive results are indicated by clear zones around the colonies. The decomposition of xanthine was tested as described by Gordon \& Mihm (1957) and that of hypoxanthine by the same test, replacing xanthine by the same amount of hypoxanthine. Tyrosine degradation was investigated on plates containing glycerin $(1.5 \%)$, Ltyrosine $(0.05 \%)$, L-asparagine $(0.1 \%), \mathrm{K}_{2} \mathrm{HPO}_{4}(0.05 \%)$, $\mathrm{MgSO}_{4} \cdot 7 \mathrm{H}_{2} \mathrm{O}(0.05 \%), \mathrm{NaCl}(0.05 \%)$, trace salt solution $(0.1 \%, \mathrm{v} / \mathrm{v}), \mathrm{CuSO}_{4}(0.001 \%)$ and agarose $(1.5 \%)$; positive results are indicated by the production of a dark brown pigment around the colonies. Starch degradation was tested on plates containing nutrient broth $(0.8 \%)$, starch $(1 \%)$ and agarose $(1.5 \%)$, with a positive result indicated by clear zones around the colonies. Chitin degradation was investigated on plates containing bleached chitin powder $(0.4 \%)$, $\mathrm{K}_{2} \mathrm{HPO}_{4} \quad(0.07 \%), \quad \mathrm{KH}_{2} \mathrm{PO}_{4} \quad(0.03 \%), \quad \mathrm{MgSO}_{4} .7 \mathrm{H}_{2} \mathrm{O}$ $(0.05 \%), \mathrm{FeSO}_{4} \cdot 7 \mathrm{H}_{2} \mathrm{O}(0.001 \%), \mathrm{ZnSO}_{4} \cdot 7 \mathrm{H}_{2} \mathrm{O}(0.0001 \%)$, $\mathrm{MnCl}_{2} \cdot 4 \mathrm{H}_{2} \mathrm{O}(0.0001 \%)$ and agarose $(1.2 \%)$; positive results are indicated by clear zones around the colonies. Aesculin degradation was examined in soft-agar tubes containing yeast extract $(0.3 \%)$, aesculin $(0.1 \%)$, ammonium iron (III) citrate $(0.05 \%)$ and agarose $(0.3 \%)$; positive results are indicated by the disappearance of the fluorescence caused by the aesculin in the medium. Furthermore, the use of Dglucose, L-arabinose, sucrose, D-xylose, i-inositol, D-mannitol, D-fructose, rhamnose and raffinose as carbon sources was examined, using carbon utilization medium (Shirling \& Gottlieb, 1966), and the utilization of L-alanine, L-arginine, Lasparagine, L-cysteine, L-glutamine, L-glycine, L-histidine, L-isoleucine, L-leucine, L-lysine, L-methionine, L-proline, Lserine, L-threonine, L-tryptophan and L-valine (all $0.1 \%$ w/v) as nitrogen sources was assessed in a basal medium consisting of D-glucose $\left(1 \%\right.$, w/v), $\mathrm{MgSO}_{4} \cdot 7 \mathrm{H}_{2} \mathrm{O}(0.05 \%), \mathrm{NaCl}$ $(0.05 \%), \mathrm{FeSO}_{4} \cdot 7 \mathrm{H}_{2} \mathrm{O}(0.001 \%), \mathrm{K}_{2} \mathrm{HPO}_{4}(0.1 \%)$ and Bacto-agar (Difco) (1.2\%), at pH 7.4. Further biochemical tests were performed as described by Meganathan et al. (2007) and Tindall et al. (2007), including alcohol dehydrogenase assay 22.7.4, indole production (15.2.39), Voges-Proskauer reaction (15.2.82), urease activity (15.2.81) and nitrate reduction/denitrification (15.2.57). Whole cell amino acids and sugars were prepared according to Lechevalier \& Lechevalier (1970) and analysed by thin layer chromatography (Staneck \& Roberts, 1974). Phospholipids were extracted, separated by two-dimensional thin layer chromatography and identified according to Minnikin et al. (1984) as modified by Kroppenstedt \& Goodfellow (2006). For the extraction of menaquinones, freeze-dried cell material was extracted with methanol as described by Collins et al. (1977) and analysed by HPLC (Kroppenstedt, 1982). Cellular fatty acids were analysed using the Microbial Identification System (MIDI) Sherlock Version 4.5, database ACTIN1, and by following described methods (Sasser, 1990). Peptidoglycan preparations purified according to the method of Schleifer (1985) were obtained after disruption of cells by shaking with glass beads and subsequent trypsin digestion. The amino acids and peptides in cell-wall hydrolysates were analysed by two-dimensional ascending thin-layer chromatography on cellulose plates by using previously described solvent systems (Schleifer, 1985). The molar ratios of amino acids were determined by gas chromatography and gas chromatography-mass spectrometry of $\mathrm{N}$-heptafluorobutyryl amino acid isobutyl esters (MacKenzie, 1987; Groth et al., 1996). The G +C content of the chromosomal DNA was determined by HPLC according to Mesbah et al. (1989). Genomic DNA extraction, PCRmediated amplification of the 16S rRNA gene and purification of the PCR product were carried out as described by Rainey et al. (1996). Phylogenetic trees were inferred by maximum-likelihood (Felsenstein, 1981) and neighbour-joining (Saitou \& Nei, 1987) algorithms, using the PHYLIP software package (Felsenstein, 1993). The resultant tree topologies were evaluated by bootstrap analysis (Felsenstein, 1985) based on 1000 resamplings using both the maximum-likelihood and neighbour-joining algorithms. The root position was estimated by using sequences of Aneurinibacillus thermoaerophilus DSM $10154^{\mathrm{T}}$ and Bacillus fortis DSM $16012^{\mathrm{T}}$ as outgroups. 
Strain JFMB-ATE ${ }^{\mathrm{T}}$ exhibited fast, abundant growth on BHI medium, producing cloudy, ivory coloured substrate mycelia (Figs 1 and 2). The white aerial mycelia were sparse. Colonies were flat, of irregular shape with undulate margin and had a dull surface which later formed radial wrinkles. Growth was also observed on GYM Streptomyces medium, while no growth occurred on yeast extract-malt extract agar, oatmeal agar, inorganic salts-starch agar, glycerol-asparagine agar, GPHF medium and trypticase soy broth agar, reflecting the fact that most Streptomyces media are not rich enough for the cultivation of species of the family Thermoactinomycetaceae. Microscopic examination revealed long, straight to flexuous, moderately branched septate hyphae, developing single endospores on unbranched sporophores and chains of arthrospores in a zigzag arrangement as previously reported for Desmospora activa (Yassin et al. 2009). Colonies of strain $\mathrm{JFMB}^{-\mathrm{ATE}^{\mathrm{T}}}$ produced no diffusible pigments on BHI or GYM medium. The investigation of melanoid pigment production by cultivation on tyrosine agar and peptoneiron agar revealed that no melanoid pigments were produced. The organism grew at temperatures between 25 and $50{ }^{\circ} \mathrm{C}$, with an optimum at $45{ }^{\circ} \mathrm{C}$. Abundant growth was observed at $\mathrm{pH} 5.0,5.5,6.0,6.5,7.0,7.5,8.0$ and 8.5 ; the $\mathrm{pH}$ variation did not detectably influence growth rate. The spore test indicated that endospores are produced, as colonies formed after exposure to $98{ }^{\circ} \mathrm{C}$ for as long as $4 \mathrm{~h}$. Casein, gelatin and aesculin were hydrolysed, while xanthine, hypoxanthine, L-tyrosine, starch and chitin were not. The chemotaxonomic properties of strain JFMB$\mathrm{ATE}^{\mathrm{T}}$ are compared with those of other genera within the family Thermoactinomycetaceae in Table 1 . The tests for carbon source utilization showed abundant growth on sucrose, i-inositol, D-mannitol and rhamnose, and weak growth on L-arabinose, D-xylose, D-fructose and raffinose, while on D-glucose, no difference from the negative control was observed. The nitrogen utilization assay revealed no growth on any of the given substrates, likely indicating that the basal medium used is not rich enough for examining species of the family Thermoactinomycetaceae. Further metabolic tests revealed a positive result for urease activity and negative results for alcohol dehydrogenase, indole production, Voges-Proskauer reaction and nitrate reduction/denitrification. Analysis of cell-wall components revealed the presence of LL-diaminopimelic acid (DAP), which is a unique feature of strain JFMB-ATE ${ }^{\mathrm{T}}$ among all presently described species of the family Thermoactinomycetaceae, and at variance with the description of the family (Matsuo et al., 2006; Yassin et al., 2009). The hydrolysate $\left(4 \mathrm{M} \mathrm{HCl}, 100{ }^{\circ} \mathrm{C}, 16 \mathrm{~h}\right)$ of the peptidoglycan preparation of strain DSM $45196^{\mathrm{T}}$ contained LL-DAP, alanine (Ala), glycine (Gly) and glutamic acid (Glu) in a molar ratio of $1.2: 0.9: 0.4: 1.0$. The partial hydrolysate (4 M $\mathrm{HCl}, 100{ }^{\circ} \mathrm{C}, 0.75 \mathrm{~h}$ ) contained in addition to these amino acids the peptides L-Ala-D-Glu and L-Lys-D-Ala. From these data it was concluded that strain DSM $45196^{\mathrm{T}}$ shows the peptidoglycan type A3 $\gamma$ LL-DAP-Gly (Schleifer \& Kandler 1972; type A41.1 according to http://www.dsmz.
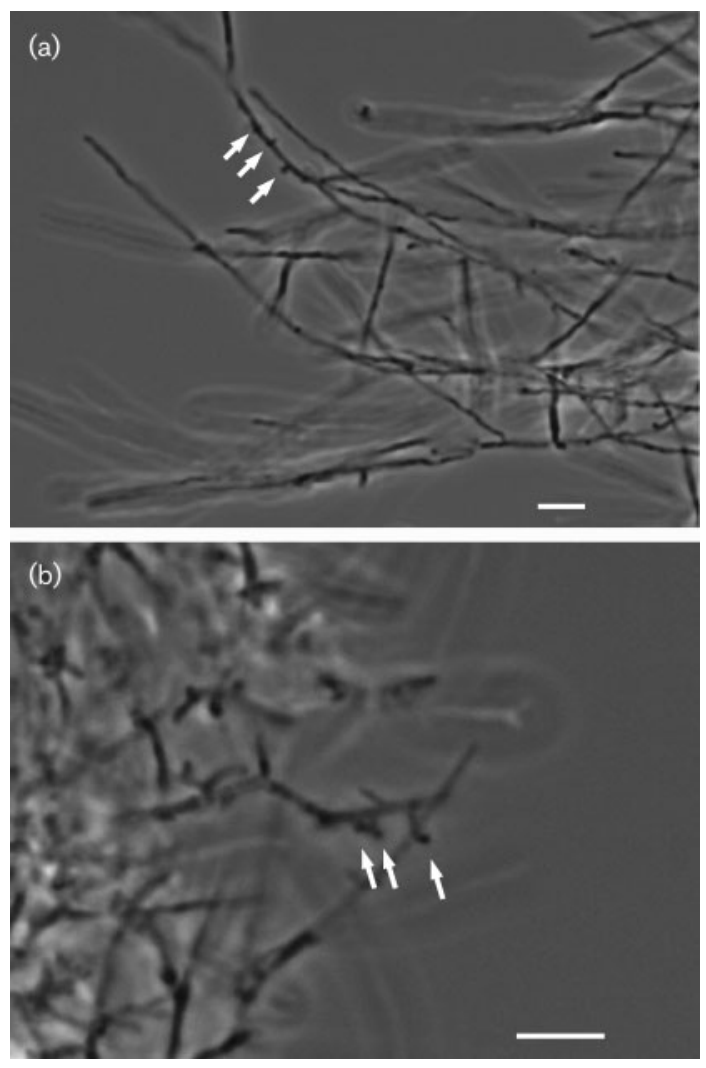

Fig. 1. Phase-contrast microscopic images showing sterile substrate mycelium of strain JFMB-ATE' ${ }^{\top}$, which was cultivated for 2 days in $\mathrm{BHI}$ medium at $40{ }^{\circ} \mathrm{C}$. Arrows in (a) mark nascent endospores, in (b) mature endospores formed singly on unbranched sporophores. Bars, $10 \mu \mathrm{m}$.

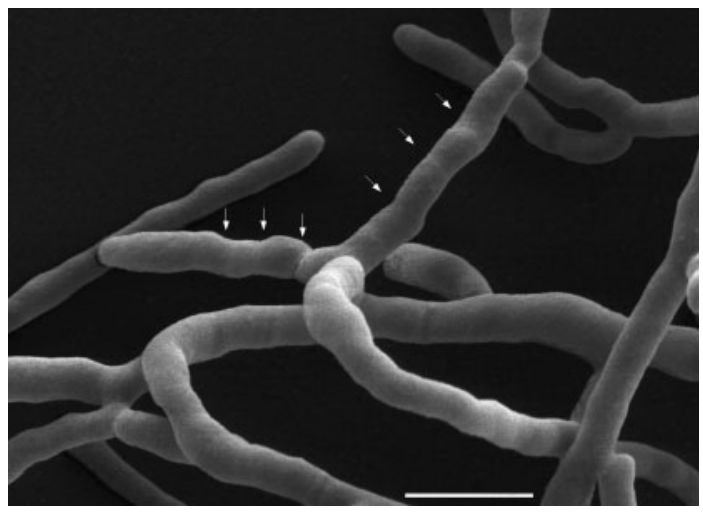

Fig. 2. Scanning electron micrograph showing sterile substrate mycelium of strain JFMB-ATE ${ }^{\top}$, which was cultivated for 2 days in $\mathrm{BHI}$ medium at $40{ }^{\circ} \mathrm{C}$. Arrows indicate positions of constriction, likely due to initiating fragmentation, representing an early stage of arthrospore formation. Bar, $1 \mu \mathrm{m}$. 
Table 1. Phenotypic and molecular genetic characteristics of strain JFMB-ATE ${ }^{\top}$ and related genera of the family Thermoactinomycetaceae

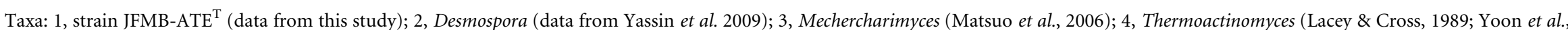

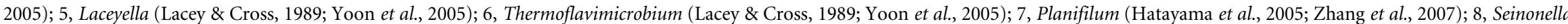
(Yoon et al., 2005); 9, Shimazuella (Park et al., 2007). +, Positive reaction; -, negative reaction; +/-, variable reaction; ND, no data available; NO, not observed.

\begin{tabular}{|c|c|c|c|c|c|c|c|c|c|}
\hline Characteristic & 1 & 2 & 3 & 4 & 5 & 6 & 7 & 8 & 9 \\
\hline Major menaquinone & MK-7 & MK-7 & MK-9 & MK-7 & MK-9 & MK-7 & MK-7 & MK-7 & MK-9 \\
\hline $\begin{array}{l}\text { Further detected } \\
\text { menaquinones }\end{array}$ & NO & $\mathrm{NO}^{*}$ & MK-8 & $\begin{array}{l}\text { MK-8 or } \\
\text { MK-9 }\end{array}$ & $\begin{array}{c}\text { MK-7, MK-8 or } \\
\text { MK-10 }\end{array}$ & $\mathrm{NO}^{*}$ & NO & $\begin{array}{l}\text { MK-8, MK-9, } \\
\text { MK-10 }\end{array}$ & MK-10 \\
\hline Major fatty acids $\dagger$ & $\begin{array}{l}\mathrm{i}-\mathrm{C}_{15: 0} \\
\text { ai- } \mathrm{C}_{15: 0}\end{array}$ & $\begin{array}{l}\mathrm{i}-\mathrm{C}_{15: 0}, \mathrm{i}- \\
\mathrm{C}_{17: 0}, \mathrm{C}_{16: 0}\end{array}$ & $\begin{array}{l}\mathrm{i}-\mathrm{C}_{15: 0} \\
\mathrm{i}-\mathrm{C}_{17: 1} \omega 11 c\end{array}$ & $\begin{array}{c}\mathrm{i}-\mathrm{C}_{15: 0}, \mathrm{i}-\mathrm{C}_{17: 0} \\
\text { ai- } \mathrm{C}_{15: 0}\end{array}$ & $\mathrm{i}-\mathrm{C}_{15: 0}$, ai $-\mathrm{C}_{15: 0}$ & $\begin{array}{l}\mathrm{i}-\mathrm{C}_{15: 0}, \text { ai- } \\
\mathrm{C}_{15: 0}, \mathrm{i}-\mathrm{C}_{16: 0}\end{array}$ & $\begin{array}{c}\mathrm{i}-\mathrm{C}_{17: 0}, \text { ai- } \mathrm{C}_{17: 0} \\
\left(\mathrm{i}-\mathrm{C}_{15: 0}, \mathrm{C}_{16: 0} \text { or }\right. \\
\left.\mathrm{i}-\mathrm{C}_{16: 0}\right)\end{array}$ & $\begin{array}{c}\mathrm{i}-\mathrm{C}_{14: 0}, \text { ai- } \mathrm{C}_{15: 0} \\
\mathrm{i}-\mathrm{C}_{16: 0}\end{array}$ & $\begin{array}{c}\mathrm{i}-\mathrm{C}_{15: 0}, \text { ai- } \mathrm{C}_{15: 0}, \\
\mathrm{i}-\mathrm{C}_{16: 0}, \mathrm{C}_{16: 0}, \\
\text { ai- } \mathrm{C}_{17: 0}\end{array}$ \\
\hline Diaminopimelic acid & LL-DAP & meso-DAP & meso-DAP & meso-DAP & meso-DAP & meso-DAP & meso-DAP & meso-DAP & meso-DAP \\
\hline DNA G + C content (mol\%) & 54.6 & 49.3 & 45.0 & 48.0 & $48.0-49.0$ & 43.0 & $56.8-60.3$ & 40.0 & 39.4 \\
\hline Colour of aerial mycelium & White & Yellow & White & White & White & Yellow & NO & White & White \\
\hline $\begin{array}{l}\text { Growth with } 25 \mu \mathrm{g} \\
\text { novobiocin } \mathrm{ml}^{-1}\end{array}$ & + & $+^{*}$ & + & + & + & + & $+^{*}$ & - & + \\
\hline \multicolumn{10}{|l|}{ Degradation of: } \\
\hline Casein & + & + & + & + & + & + & + & - & + \\
\hline Aesculin & + & + & - & + & $+/-$ & - & $+^{*}$ & $\mathrm{ND}$ & $-^{*}$ \\
\hline Gelatin & + & + & + & + & + & + & $+^{*}$ & - & - \\
\hline Starch & - & $+^{*}$ & - & - & + & - & + & - & + \\
\hline Hypoxanthine & - & - & - & - & - & + & - & - & - \\
\hline Xanthine & - & - & - & - & - & + & - & - & - \\
\hline L-Tyrosine & - & - & - & $+/-$ & $+/-$ & - & $+1-$ & - & - \\
\hline $\begin{array}{l}\text { Optimal temperature for } \\
\text { growth }\left({ }^{\circ} \mathrm{C}\right)\end{array}$ & 45 & $30-50$ & 30 & $50-55$ & $48-55$ & 55 & $55-70$ & 35 & 32 \\
\hline
\end{tabular}

${ }^{\star}$ Data from this study, based on experiments with the type strains of D. activa, T. dichotomicum, P. fulgidum, P. fimeticola and S. kribbensis.

†Only components making up $>10 \%$ peak area ratio are shown. 
de/microorganisms/main.php?content_id=35). Moreover, strain JFMB-ATE ${ }^{\mathrm{T}}$ displayed only menaquinone MK-7. Major fatty acids were saturated branched-chain acids: iso$\mathrm{C}_{15: 0}(73.3 \%)$, anteiso- $\mathrm{C}_{15: 0}(13.1 \%)$, iso- $\mathrm{C}_{16: 0}(4.5 \%)$ and iso- $\mathrm{C}_{14: 0}(3.9 \%)$. The phospholipid pattern consisted of diphosphatidylglycerol, phosphatidylethanolamine, phosphatidylglycerol and unknown phospholipids, typical of phospholipid pattern type PII sensu Lechevalier et al. 1977. Whole-cell sugar analysis revealed only the presence of glucose and ribose; no diagnostic sugars were detected (Lechevalier \& Lechevalier, 1970). The G $+\mathrm{C}$ content of the chromosomal DNA was $54.6 \mathrm{~mol} \%$. Previously unreported properties of genera of the family Thermoactinomycetaceae were determined in this study (see Table 1), based on experiments with D. activa (DSM 45169 $9^{\mathrm{T}}$ ), Thermoflavimicrobium dichotomicum (DSM $44778^{\mathrm{T}}$ ), Planifilum fulgidum (DSM $44945^{\mathrm{T}}$ ), Planifilum fimeticola (DSM $44946^{\mathrm{T}}$ ) and Shimazuella kribbensis (DSM $45090^{\mathrm{T}}$ ). Results for the degradation of aesculin by members of the genus Planifilum were only obtained from P. fimeticola, as growth of $P$. fulgidum was not observed in our analyses.

Using EzTaxon (Chun et al., 2007) for comparison of the $16 \mathrm{~S}$ rRNA gene sequence of strain JFMB-ATE ${ }^{\mathrm{T}}$ with those of the type species within the family Thermoactinomycetaceae with validly published names revealed the highest degree of sequence similarity with $P$. fimeticola $(93.1 \%), D$. activa (93.0\%), Planifilum yunnanense (93.0\%), P. fulgidum (92.9\%), Mechercharimyces mesophilus (92.1\%), Laceyella putida (91.9\%), Mechercharimyces asporophorigenens (91.8\%), Laceyella sacchari $(91.7 \%)$, Thermoactinomyces intermedius (91.3\%), Thermoflavimicrobium dichotomicum (91.0\%) and Thermoactinomyces vulgaris (91.0\%). Both the maximumlikelihood and neighbour-joining phylogenetic trees demonstrate that strain JFMB-ATE ${ }^{\mathrm{T}}$ clusters nearest to the genus Planifilum; however, the high degree of 16S rRNA gene sequence dissimilarity $(\geqslant 6.9 \%)$ indicates only a distant relationship.

Several phenotypic characteristics, apart from the phylogenetic analysis based on $16 \mathrm{~S}$ rRNA gene sequences, also support the distinctiveness of strain JFMB-ATE ${ }^{\mathrm{T}}$ from all other described members of the family Thermoactinomycetaceae (see Table 1). In particular, a unique feature of this strain is the presence of LL-DAP in the cell-wall peptidoglycan rather than the meso isomer which is present in all other members of this family. Moreover, strain JFMB-ATE ${ }^{\mathrm{T}}$ differs from the majority of taxa within the family Thermoactinomycetaceae, with the exception of the genus Planifilum, by having a significantly higher DNA G +C content. The topology of the phylogenetic tree (Fig. 3), where strain JFMB-ATE ${ }^{\mathrm{T}}$ clusters with the genus Planifilum, possibly suggests that the tendency towards high G+C DNA composition is a specific development of the common branch containing the genus Planifilum and strain JFMB-ATE ${ }^{\mathrm{T}}$. However, the latter is clearly distinct from the genus Planifilum, not only by $16 \mathrm{~S}$ rRNA gene sequence divergence and the presence of LL-DAP in the peptidoglycan, but also by iso- $\mathrm{C}_{15: 0}$ and anteiso- $\mathrm{C}_{15: 0}$ as the major fatty acids versus iso- $\mathrm{C}_{17: 0}$ and anteiso- $\mathrm{C}_{17: 0}$ as the dominant fatty acids in members of the genus Planifilum. Likewise, the fatty acid composition also differentiates strain JFMB-ATE $^{\mathrm{T}}$ from the members of the genus Seinonella, while the major menaquinone differentiates it from the genera Mechercharimyces, Laceyella and Shimazuella. Finally, strain JFMB-ATE $^{\mathrm{T}}$ further differs from members of the genus Shimazuella by the ability to hydrolyse gelatin and by the inability to hydrolyse starch.

\section{Description of the genus Kroppenstedtia gen. nov.}

Kroppenstedtia (Krop.pen.sted'ti.a. N.L. fem. n. Kroppenstedtia named in honour of Reiner M. Kroppenstedt, a German microbiologist, who has contributed significantly to the field of bacterial taxonomy).

Cells are aerobic, Gram-positive and chemoorganotrophic. Thermotolerant growth occurs between 25 and $50{ }^{\circ} \mathrm{C}$, and at $\mathrm{pH}$ 5.0-8.5. Substrate and aerial mycelia are formed, both producing chains of arthrospores and heat-resistant endospores, the latter are formed singly on unbranched sporophores. The predominant menaquinone is MK-7. Major fatty acids are iso- $\mathrm{C}_{15: 0}$ and anteiso- $\mathrm{C}_{15: 0}$. The cell wall peptidoglycan contains LL-DAP and is of type A3 $\gamma$ LL-DAP-Gly (Schleifer \& Kandler, 1972). Diagnostic sugars

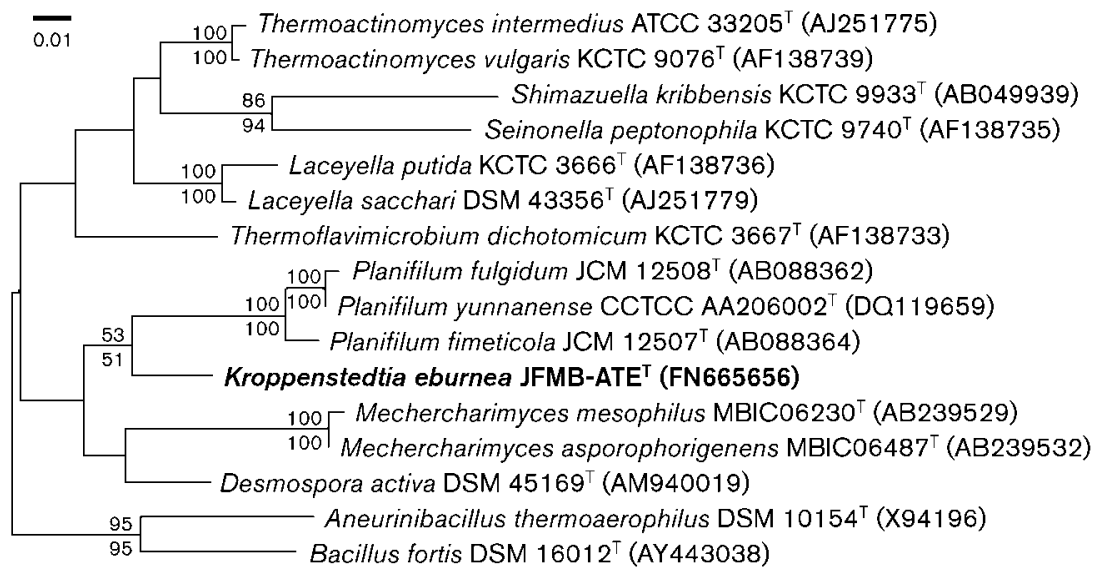

Fig. 3. Maximum-likelihood phylogenetic tree based on 16S rRNA gene sequences, showing the phylogenetic position of strain JFMB$\mathrm{ATE}^{\top}$ in relation to type strains of the family Thermoactinomycetaceae. Bar, 0.01 substitutions per nucleotide position. Bootstrap values greater than $50 \%$ are shown at branch points; values above branches refer to calculations based on the maximum-likelihood algorithm; values below branches are based on neighbour-joining. 
are not detected in whole-cell hydrolysates, implying cellwall chemotype I sensu Lechevalier \& Lechevalier, 1970. The phospholipid pattern predominantly consists of diphosphatidylglycerol, phosphatidylethanolamine and phosphatidylglycerol, indicating phospholipid pattern type PII sensu (Lechevalier et al., 1977). The DNA G +C content of the type strain of the type species is $54.6 \mathrm{~mol} \%$. The type species is Kroppenstedtia eburnea.

\section{Description of Kroppenstedtia eburnea sp. nov.}

Kroppenstedtia eburnea (e.bur'ne.a. L. fem. adj. eburnea of ivory, referring to the colony colour of the type strain).

Colonies are ivory coloured, cloudy, flat and of irregular shape with undulate margin and a dull surface, forming radial wrinkles and sparse white aerial mycelia. No diffusible pigments are produced on BHI and GYM media and no melanoid pigments on peptone-iron agar. Casein, gelatin and aesculin are hydrolysed; starch, xanthine, hypoxanthine, chitin and L-tyrosine are not hydrolysed. Urease reaction is positive. Alcohol dehydrogenase, indole production, nitrate reduction/denitrification and VogesProskauer reaction are negative.

The type strain, JFMB-ATE ${ }^{\mathrm{T}}$ (=DSM $45196^{\mathrm{T}}=$ NRRL B$24804^{\mathrm{T}}=$ CCUG $59226^{\mathrm{T}}$ ) was isolated during environmental screening of a plastic surface in grade $\mathrm{C}$ in a contract manufacturing organization in southern Germany.

\section{Emended description of the family Thermoactinomycetaceae Matsuo et al. 2006 emend. Yassin et al. 2009}

Thermoactinomycetaceae (Ther'mo.ac.ti.no.my.ce.ta'ce.ae. N.L. masc. n. Thermoactinomyces type genus of the family; -aceae ending to denote a family; N.L. fem. pl. n. Thermoactinomycetaceae the Thermoactinomyces family).

The description of the family Thermoactinomycetaceae is as given by Yassin et al. (2009), with the following amendment: cell walls contain meso-diaminopimelic acid (meso-DAP) or LL-diaminopimelic acid (LL-DAP).

\section{Acknowledgements}

We would like to gratefully acknowledge the help of Nicole Mrotzeck for 16S rRNA gene sequencing and, furthermore, the help of Anja Frühling for the phase-contrast light microscopic analysis and the processing of metabolic examinations.

\section{References}

Chun, J., Lee, J.-H., Jung, Y., Kim, M., Kim, S., Kim, B. K. \& Lim, Y. W. (2007). EzTaxon: a web-based tool for the identification of prokaryotes based on $16 \mathrm{~S}$ ribosomal RNA gene sequences. Int J Syst Evol Microbiol 57, 2259-2261.

Collins, M. D., Pirouz, T., Goodfellow, M. \& Minnikin, D. E. (1977). Distribution of menaquinones in actinomycetes and corynebacteria. J Gen Microbiol 100, 221-230.
Cross, T., Walker, P. D. \& Gould, G. W. (1968). Thermophilic actinomycetes producing resistant endospores. Nature 220, 352-354.

Felsenstein, J. (1981). Evolutionary trees from DNA sequences: a maximum likelihood approach. J Mol Evol 17, 368-376.

Felsenstein, J. (1985). Confidence limits on phylogenies: an approach using the bootstrap. Evolution 39, 783-791.

Felsenstein, J. (1993). PHYLIP (phylogenetic inference package) version 3.5c. Distributed by the author. Department of Genome Sciences, University of Washington, Seattle, USA.

Gordon, R. E. \& Mihm, J. M. (1957). A comparative study of some strains received as nocardiae. J Bacteriol 73, 15-27.

Groth, I., Schumann, P., Weiss, N., Martin, K. \& Rainey, F. A. (1996). Agrococcus jenensis gen. nov., sp. nov., a new genus of actinomycetes with diaminobutyric acid in the cell wall. Int J Syst Bacteriol 46, 234-239.

Hatayama, K., Shoun, H., Ueda, Y. \& Nakamura, A. (2005). Planifilum fimeticola gen. nov., sp. nov. and Planifilum fulgidum sp. nov., novel members of the family 'Thermoactinomycetaceae' isolated from compost. Int J Syst Evol Microbiol 55, 2101-2104.

Kroppenstedt, R. M. (1982). Separation of bacterial menaquinones by HPLC using reverse phase (RP18) and a silver loaded ion exchanger. J Liq Chromatogr 5, 2359-2367.

Kroppenstedt, R. M. \& Goodfellow, M. (2006). The family Thermomonosporaceae. In The Prokaryotes, 3rd edn vol. 3, pp. 682724. Edited by M. Dworkin, N. Falkow, E. Rosenberg, K. H. Schleifer \& E. Stackebrandt. New York: Springer.

Lacey, J. \& Cross, T. (1989). Genus Thermoactinomyces Tsiklinsky $1899,501^{\mathrm{AL}}$. In Bergey's Manual of Systematic Bacteriology, vol. 4, pp. 2574-2585. Edited by S. T. Williams, M. E. Sharpe \& J. G. Holt. Baltimore: Williams \& Wilkins.

Lechevalier, M. P. \& Lechevalier, H. A. (1970). Chemical composition as a criterion in the classification of aerobic actinomycetes. Int J Syst Bacteriol 20, 435-443.

Lechevalier, M. P., De Bièvre, C. \& Lechevalier, H. A. (1977). Chemotaxonomy of aerobic actinomycetes: phospholipid composition. Biochem Syst Ecol 5, 249-260.

MacKenzie, S. L. (1987). Gas chromatographic analysis of amino acids as the $\mathrm{N}$-heptafluorobutyryl isobutyl esters. J Assoc Off Anal Chem 70, 151-160.

Matsuo, Y., Katsuta, A., Matsuda, S., Shizuri, Y., Yokota, A. \& Kasai, H. (2006). Mechercharimyces mesophilus gen. nov., sp. nov. and Mechercharimyces asporophorigenens sp. nov., antitumour substanceproducing marine bacteria, and description of Thermoactinomycetaceae fam. nov. Int J Syst Evol Microbiol 56, 2837-2842.

Meganathan, R., Ranganathan, Y. \& Reddy, C. A. (2007). Carbohydrate fermentations. In Methods for General and Molecular Microbiology, 3rd edn, pp. 558-585. Edited by C. A. Reddy, T. J. Beveridge, J. A. Breznak, G. A. Marzluf, T. M. Schmidt \& L. R. Snyder. Washington, DC: American Society for Microbiology.

Mesbah, M., Premachandran, U. \& Whitman, W. B. (1989). Precise measurement of the $\mathrm{G}+\mathrm{C}$ content of deoxyribonucleic acid by highperformance liquid chromatography. Int J Syst Bacteriol 39, 159-167.

Minnikin, D. E., O’Donnell, A. G., Goodfellow, M., Alderson, G., Athalye, M., Schaal, K. \& Parlett, J. H. (1984). An integrated procedure for the extraction of bacterial isoprenoid quinones and polar lipids. J Microbiol Methods 2, 233-241.

Park, D.-J., Dastager, S.-G., Lee, J.-C., Yeo, S.-H., Yoon, J.-H. \& Kim, C.-J. (2007). Shimazuella kribbensis gen. nov., sp. nov., a mesophilic representative of the family Thermoactinomycetaceae. Int J Syst Evol Microbiol 57, 2660-2664.

Rainey, F. A., Ward-Rainey, N., Kroppenstedt, R. M. \& Stackebrandt, E. (1996). The genus Nocardiopsis represents a phylogenetically 
coherent taxon and a distinct actinomycete lineage: proposal of Nocardiopsiaceae fam. nov. Int J Syst Bacteriol 46, 1088-1092.

Saitou, N. \& Nei, M. (1987). The neighbor-joining method: a new method for reconstructing phylogenetic trees. Mol Biol Evol 4, 406425.

Sasser, M. (1990). Identification of bacteria by gas chromatography of cellular fatty acids. USFCC Newsl 20, 16.

Schleifer, K. H. (1985). Analysis of the chemical composition and primary structure of murein. Methods Microbiol 18, 123-156.

Schleifer, K. H. \& Kandler, O. (1972). Peptidoglycan types of bacterial cell walls and their taxonomic implications. Bacteriol Rev 36, 407-477.

Shirling, E. B. \& Gottlieb, D. (1966). Methods for characterization of Streptomyces species. Int J Syst Bacteriol 16, 313-340.

Stackebrandt, E. \& Woese, C. R. (1981). Towards a phylogeny of the actinomycetes and related organisms. Curr Microbiol 5, 197-202.

Staneck, J. L. \& Roberts, G. D. (1974). Simplified approach to identification of aerobic actinomycetes by thin-layer chromatography. Appl Microbiol 28, 226-231.
Tindall, B. J., Sikorski, J., Simbert, R. A. \& Krieg, N. R. (2007). Phenotypic characterization and the principles of comparative systematics. In Methods for General and Molecular Microbiology, 3rd edn, pp. 330-393. Edited by C. A. Reddy, T. J. Beveridge, J. A. Breznak, G. A. Marzluf, T. M. Schmidt \& L. R. Snyder. Washington, DC: American Society for Microbiology.

Yassin, A. F., Hupfer, H., Klenk, H.-P. \& Siering, C. (2009). Desmospora activa gen. nov., sp. nov., a thermoactinomycete isolated from sputum of a patient with suspected pulmonary tuberculosis, and emended description of the family Thermoactinomycetaceae Matsuo et al. 2006. Int J Syst Evol Microbiol 59, 454-459.

Yoon, J.-H., Kim, I.-G., Shin, Y.-K. \& Park, Y.-H. (2005). Proposal of the genus Thermoactinomyces sensu stricto and three new genera, Laceyella, Thermoflavimicrobium and Seinonella, on the basis of phenotypic, phylogenetic and chemotaxonomic analyses. Int J Syst Evol Microbiol 55, 395-400.

Zhang, Y. X., Dong, C. \& Biao, S. (2007). Planifilum yunnanense sp. nov., a thermophilic thermoactinomycete isolated from a hot spring. Int J Syst Evol Microbiol 57, 1851-1854. 